\title{
IDENTIFIKASI AKSEN TUTURAN REPRESENTATIF BAHASA JAWA DIALEK BANTEN: PENDEKATAN FONETIK AKUSTIK
}

Identification of Representative Speech Accents for Javanese Banten Dialect: Acoustic

Phonetic Approach

\section{Wawan Prihartono}

Badan Pengembangan dan Pembinaan Bahasa

wawanpri@gmail.com

\section{Naskah Diterima Tanggal 29 September 2019-Direvisi Akhir Tanggal 15 Oktober 2020-Disetujui Tanggal 15 November 2020} doi: https://doi.org/10.26499/rnh.v9i2.2926

\begin{abstract}
Abstrak
Penelitian ini mengidentifikasi parameter akustik aksen tuturan representatif bahasa Jawa dialek Banten dengan menggunakan teori fonetik akustik yang dikembangkan oleh Nooteboom dan kawankawan. Penelitian ini merupakan studi kasus yang menggunakan metode campuran kuantitatif dan kualitatif. Data tuturan bahasa Jawa dialek Banten dituturkan oleh perempuan dewasa yang tinggal di kota Serang, Provinsi Banten. Penelitian ini menganalisis aksen tuturan representatif bahasa Jawa dialek Banten yang diolah menggunakan aplikasi praat. Durasi diukur dalam satuan milidetik, intensitas diukur dalam satuan $\mathrm{dB}$, dan pitch movement-nya diukur dalam satuan $\mathrm{Hz}$. Hasilnya, tuturan representatif dalam dalam bahasa Jawa Dialek Banten memiliki struktur akustik yang kompleks dan menjadi ciri khas tuturan bahasa Jawa Dialek Banten. Hal ini terdeteksi pada silabel $/ \mathrm{k} ə n / \mathrm{dan} / \mathrm{ke} /$. Pada silabel itu ditandai alir nada naik, turun, naik, dan turun kembali dengan durasi yang lebih panjang daripada silabel yang lain. Hasil penelitian ini dapat dijadikan bahan dasar untuk merekonstruksi bahasa Jawa Dialek Banten khususnya struktur akustiknya jika di kemudian hari bahasa tersebut telah dianggap punah. Setelah itu dapat dijadikan muatan lokal dalam pembelajaran di sekolah.
\end{abstract}

Kata-kata Kunci: parameter akustik, tuturan bahasa Jawa dialek Banten

\begin{abstract}
This study uses speech acoustic parameters representing the Javanese dialect of Banten using the acoustic phonetic theory developed by Nooteboom and friends. This research is a case study that uses a mixture of quantitative and qualitative methods. Data on spoken Javanese in Banten dialect is spoken by adult women living in the city of Serang, Banten Province. This study only analyzes data representing the Banten dialect Javanese that can be processed using praat applications. The duration is determined in milliseconds, the intensity is measured in units of $d B$, and the pitch motion is measured in units of $\mathrm{Hz}$. How, speech representing in Javanese Banten dialect has an acoustic structure that is quite complex and has special characteristics. This is detected in the syllables /kan / and /ke/. In this syllable, the flow of notes is marked up, down, up, and down again with a longer duration than the other syllables.The results of this study can be made the basic material for reconstructing the Banten dialect Javanese specifically its acoustic structure in the future if the language has been approved extinct.After that it can be used as local content in learning at school. Keywords: parameters acoustics, Java Banten dialectspeech
\end{abstract}

How to Cite: Prihartono, Wawan. (2020). Identifikasi Aksen Tuturan Representatif Bahasa Jawa Dialek Banten: Pendekatan Fonetik Akustik. Ranah: Jurnal Kajian Bahasa. 9(2). 400-412. doi: https://doi.org/10.26499/rnh.v9i2.2926 


\section{PENDAHULUAN}

Bahasa Jawa Dialek Banten merupakan salah satu aset bangsa yang perlu terus dikembangkan supaya terhindar dari kepunahan bahasa (language death). Selama ini fenomena kepunahan bahasa selalu saja terjadi karena kurangnya perhatian yang serius terhadap bahasa tersebut. Padahal fenomena ini bisa diantisipasi sedini mungkin dengan melakukan tindakan yang sistematis.Bahasa dikategorikan akan mengalami kepunahan apabila bahasa tersebut tidak dikembangkan oleh penuturnya. Lebih parah lagi jika bahasa tersebut sengaja ditinggalkan oleh penuturnya.Dengan kata lain, bahasa itu telah mati.

Bahasa yang ditinggalkan penuturnya dan mengalami kepunahan biasa disebabkan oleh adanya situasi bilingualisme. Bahasa yang dominan terus menggerus eksistensi bahasa yang tidak dominan sehingga terjadilah pengalihan bahasa (language shift).

Fenomena kepunahan bahasa karena bilingualisme rentan terjadi di Indonesia. Hal ini disebabkan oleh faktor politik bahasa yang diterapkan di Indonesia. Bahasa Indonesia diangkat sebagai bahasa negara dan bahasa nasional, secara tidak langsung mengakibatkan tersisihnya bahasa-bahasa daerah di Indonesia. Dengan diangkatnya bahasa Indonesia sebagai bahasa negara dan bahasa nasional berarti bahasa Indonesia memiliki nilai strategis yang pemakaiannya sangat mendominasi. Hal ini menyebabkan penutur bahasanya pun mengalami pertumbuhan yang signifikan, padahal penuturnya tersebut tak lain adalah pemilik atau pewaris bahasa daerah yang ada di Indonesia itu sendiri. Contohnya adalah penggunaan bahasa Indonesia oleh masyarakat Jawa di pesisir pantai barat Jawa, yaitu Banten. Pada dasarnya mereka adalah penutur bahasa Jawa dialek Banten. Namun, dominasi pemakaian bahasa Indonesia di segala ranah menggerus eksistensi bahasa Jawa dialek Banten itu. Bahasa Jawa dialek Banten tidak lagi digunakan dalam ranah keluarga serta ranah pendidikan tingkat dini dan dasar. Niscaya, bahasa jawa dialek Banten akan mengalami kepunahan.

Upaya penyelamatan bahasa Jawa dialek Banten harus dilakukan secara masif karena bahasa tersebut adalah media penyampai nilai sosial dan kearifan lokal masyarakat pemiliknya. Upaya penyelamatan bisa dimulai dari hal-hal yang cukup sederhana, seperti gerakan penggunaaan bahasa Jawa dialek Banten dalam berbagai ranah sosial masyarakat pemiliknya,membuat film-film dokumenter dalam bahasa Jawa dialek Banten, dan kajiankajian ilmiah yang komprehensif.

Dokumentasi dan penelitian-penelitian ilmiah terhadap bahasa Jawa dialek Banten, seperti pembuatan kamus dwibahasa, penyusunan buku tentang struktur tata bahasa bahasa Jawa dialek Banten, baik dari segi fonologi sampai dengan semantik, dan penelitian-penelitian 
lainnya harus terus dilakukan untuk menunjang vitalitas bahasa Jawa dialek Banten. Mungkin juga bisa dilakukan dengan pembelajaran bahasa Jawa tersebut sebagai muatan lokal di daerah itu. Makin banyak kajian dan ulasan terhadap bahasa Jawa dialek Banten berarti menambah daya hidup atau vitalitas bahasa Jawa dialek Banten. Makin banyak generasi muda suku Jawa dialek Banten yang melestarikan dan mengembangkan bahasa Jawa dialek Banten berarti makin kuat daya vitalitas bahasa Jawa dialek Banten. Makin kuat perhatian pemerintah, baik pemerintah pusat dan pemerintah daerah terhadap bahasa Jawa Dialek Banten, berarti makin kokoh daya tahan bahasa Jawa dialek Banten. Dengan memperkuat daya vitalitas bahasa Jawa dialek Banten berarti turut memperkuat pula eksistensi bahasa dan budaya Indonesia karena bahasa dan budaya Indonesia dibangun atas unsur-unsur bahasa dan budaya daerah. Tidak ada bahasa dan budaya Indonesia jika bahasa dan budaya daerah punah atau mati. Tidak ada bangsa Indonesia jika suku bangsa di Indonesia kehilangan identitasnya.

Selama ini telah banyak penelitian dan kajian terhadap bahasa Jawa dialek Banten, seperti Variasi Pilihan Bahasa pada Masyarakat Serang: Penelitian Etnografis pada Masyarakat Dwibahasawan Jawa Dialek Banten-Indonesia (2015), Peristiwa Tutur Bahasa Jawa Serang dan Sunda Serang di Provinsi Banten (2010), Status Kebahasaan Jawa-Sunda dan Bilingualisme di Kabupaten Tangerang, Banten (2011), dan masih banyak penelitianpenelitian lain yang berkaitan dengan bahasa Jawa dialek Banten. Penelitian itu semua dijadikan data sekunder dalam penelitian ini karena penelitian ini juga membahas bahasa Jawa Dialek Banten meskipun sudut pandang dan fokus objek kajiannya berbeda.Semua penelitian itu tentunya dapat membantu mempertahankan daya vitalitas bahasa Jawa dialek Banten.

Penelitian ini akan mengidentifikasi tuturan representatif yaitu tuturan yang mengikat penuturnya akan kebenaran atas sesuatu yang diujarkan, seperti menyatakan sesuatu, menuntut sesuai, mengakui sesuai, melaporkan, menunjukkan sesuai, menyebutkan, memberikan sesuai, kesaksian, dan berspekulasi. Tuturan representatif bahasa Jawa dialek Banten yang akan diidentifikasi adalah wes ta? siapakən bescke. Ada ciri khas dalam tuturan bahasa Jawa dialek Banten. Produksi ujaran /ken/ pada dialek tersebut berbeda dengan $/ \mathrm{ken} /$ pada bahasa Jawa standar.

Kegiatan identifikasi tuturan meliputi pendeskripsian durasi tuturan per segmen, pendeskripsian karakter nada tuturan per segmen, dan pendeskripsian karakter intensitas tuturan per segmen juga. Hasilnya dapat dimanfaatkan untuk menambahkan kajian vitalitas bahasa Jawa dialek Banten, khususnya dalam rangka membuat kontruksi tuturan secara 
fonetik akustik. Jika suatu saat nanti dijadikan muatan lokal dalam pembelajaran formal di sekolah tingkat dasar, dasar referensi keilmiahan bahasa Jawa dialek Banten sudah tersedia.

\section{LANDASAN TEORI}

Fonetik akustik melibatkan studi produksi ujaran dan persepsi pada tingkat gramatikal yang lebih tinggi, terutama fonologi. Tahapannya bermula pada bagaimana sinyal ujaran dihasilkan oleh penutur, bagaimana sinyal-sinyal tersebut dipersepsikan oleh pendengar, dan bagaimana sinyal-sinyal tersebut distrukturkan dalam fonologi bahasa. Model akustik produksi ujaran menghitung forman frekuensi, frekuensi dasar, spektrum amplitudo/intensitas dan durasi yang digunakan untuk menggambarkan varietas bahasa fonetik. Hasil diinterpretasikan dalam kerangka fonologis. Fokusnya terletak pada bahasa kurang dijelaskan dan varietas bahasa. Penutur (speaker) varian khusus memainkan peranan penting dalam pengenalan penutur.

Obyek kajian fonetik akustik adalah sinyal ujaran akustik (acoustic speech signals) sebagai gejala fisika. Selanjutnya, dikembangkan dalam bentuk simbiosis dengan kajian produk ujaran, persepsi ujaran, dan ilmu kebahasaan. Dengan kata lain, kajian ini tidak lagi mengabaikan bagaimana sinyal dihasilkan dan dipersepsikan, dan bagaimana sinyal tersebut distrukturisasi secara linguistik.

\section{METODE PENELITIAN}

Metode yang digunakan dalam penelitian ini adalah metode campuran antara kuantitatif dan kualitatif. Data kontinum kuantitatif dideskripsikan secara kualitatif untuk memperdalam kajian dalam penelitian ini. Data berupa rekaman dialog yang dituturkan oleh penutur perempuan dewasa. Data didapat dari dokumentasi audio visual bahasa Jawa dialek Banten. Data diolah dengan menggunakan aplikasi praat 6023_win32 yang sebelumnya telah dipasang di Laptop merk Samsung Core ${ }^{\mathrm{TM}_{\mathrm{i}}}$. Langkah-langkahnya adalah sebagai berikut. Rekaman dialog panjang yang dilakukan oleh tiga perempuan Jawa yang tinggal di Banten disegmentasi menjadi bagian-bagian tuturan dengan menggunakan aplikasi Adobe Audition 1.0 yang sebelumnya juga telah dipasang di laptop. Aplikasi Adobe Audition 1.0 juga digunakan untuk mengubah format data dari MP3 menjadi Microsoft Sound Waves supaya mudah dianalisis menggunakan aplikasi praat versi terbaru. Tahap selanjutnya adalah analisis data penelitian menggunakan aplikasi praat tersebut, yaitu (1) digitalisasi, (2) pembuatan text grid, 
pembuatan salinan kontur nada, (3) pembuatan salinan kontur intensitas,dan (4) deskripsi temuan penelitian.

Data hasil rekaman manual diubah ke dalam bentuk digital menggunakan aplikasi praat. Hal ini dinamakan digitalisasi. Dengan kata lain, data tuturan yang berbentuk Microsoft Waves Sound Format (WAV) diubah ke bentuk digital dengan menggunakan aplikasi praat. Digitalisasi menghasilkan sinyal akustik yang berbentuk gelombang bunyi sebuah tuturan. Dalam tahap digitalisasi juga dapat dilakukan proses pengeditan suara dengan melakukan ekstraksi sinyal akustik. Maksudnya, tuturan dalam bentuk kurva melodik disesuaikan potongannya seakurat mungkin dengan melakukan ekstrak sinyal akustik berdasarkan posisi tuturan yang ada sehingga akan didapat sinyal akustik yang sesuai dengan ukuran durasi tuturan yang sebenarnya. Tidak ada ruang kosong (space) di awal dan di akhir ujaran yang dapat menyulitkan dalam proses analisis sinyal akustik nantinya. Ruang kosong ini ditandai dengan noise yang tidak ada hubungannya dengan bunyi ujaran. Bahkan hanya berupa garis tanpa suara.

Tahap selanjutnya dilakukan segmentasi tuturan. Segmentasi tuturan dilakukan dengan memilah bunyi per bunyi pada ujaran yang sudah didigitalisasi sebelumnya berdasarkan analisis forman dan sinyal akustik yang tertera dalam gambar di aplikasi praat. Dalam tahap ini bunyi disegmentasikan berdasarkan posisinya masing-masing. Bunyi kontoid biasanya didominasi bunyi tak bersuara yang memiliki karakter forman yang relatif terang dan karakter sinyal akustik dengan intensitas rendah bahkan sering ditandai dengan garis horizontal saja. Sebaliknya, bunyi vokoid biasanya didominasi bunyi bersuara dengan karakter spektrum yang relatif gelap dan karakter sinyal akustik dengan intensitas dominan atau tinggi bahkan sering ditandai dengan intensitas gelombang yang tinggi. Tahapan ini dilakukan untuk menentukan durasi bunyi silabis pada ujaran yang disegmentasikan.

Tahap selanjutnya dilakukan proses identifikasi struktur melodik tuturan melalui proses manipulasi tuturan. Dengan kata lain, proses manipulasi dilakukan untuk memperoleh gambaran kurva melodik sebuah ujaran yang akan diidentifikasi. Kurva melodik tersebut merupakan kontur frekuensi atau kontur nada ujaran yang menggambarkan rangkaian frekuensi atau nada yang berjumlah banyak dan memiliki pola yang bermacam-macam, tergantung karakter ujarannya. Untuk mengidentifikasi dan menganalisis kontur frekuensi atau kontur nada bisa dilakukan dengan menyederhanakan kontur nada.Hal ini dilakukan untuk mempermudah analisis karena kontur frekuensi atau kontur nada hasil penyederhanaan berupa titik (poin) per titik yang lebih sederhana. Berbeda sekali dengan sebelum 
disederhanakan, titik-titik pemarkah frekuensi atau nada berjumlah tak terhitung dan dalam posisi yang sangat rapat sehingga menyulitkan dalam menganalisisnya.

Penelitian ini menentukan frekuensi intonasi untuk mengidentifikasi tuturan. Hanya saja struktur melodik tuturan tidak dideskripsikan secara bersamaan atau secara utuh, melainkan struktur melodik tuturan dibagi atas unsur silabel yang membangunnya. Dengan kata lain, alir nada (pitch movement) atau yang biasa disebut local attributes dalam silabel dideskripsikan secara detail sehingga struktur nada (pitch contours) atau yang biasa disebut global attributes tuturan dapat rinci secara detail pula. Nada-nada tersebut diukur dengan satuan $\mathrm{Hertz}(\mathrm{Hz})$.

\section{PEMBAHASAN}

Tuturan representatif wes ta? siapakan bescke dituturkan oleh perempuan suku bangsa Jawa dengan rentang usia 40-50 tahun yang tinggal di Serang, Provinsi Banten. Pada rentang usia tersebut, perempuan tidak lagi mengalami perkembangan fisiologi pada organ ucapnya. Tuturan representatif wes ta? siapakən besekedilakukan secara spontan pada dialog biasa dengan dua orang tetangganya. Tema tuturan adalah rencana kunjungan acara ke Kampung Jrakah. Si penutur sudah menyiapkan bingkisan (besek) dalam rencana kunjungan tersebut dengan mengucapkan wes ta? siapakən bescke. Berdasarkan realisasi tuturan tersebut dapat dipastikan bahwa tuturan representatif wes ta? siapakən bescke tidak dikondisikan sedemikian rupa. Hal ini menguatkan asumsi bahwa tuturan tersebut benar-benar autentik atau asli sebagai tuturan representatif bahasa Jawa dialek Banten yang sebenarnya atau tidak direkayasa.

Identifikasi tuturan representatif wes ta? siapakən bescke diawali dengan proses digitalisasi tuturan, segmentasi bunyi, identifikasi kontur nada, dan identifikasi kontur intensitas tuturan. Hasil digitalisasi menghasilkan sinyal akustik gelombang suara tuturan representatif wes ta? siapakan bescke. Sinyal tersebut kemudian disegmentasi berdasarkan bunyi pada satuan silabe. Berdasarkan hal tersebut di atas berarti tuturan representatif wes ta? siapakən besckedibangun atas sembilan unsur silabe, yaitu /wes/, /ta?/, /si/, /ap/,/a/,/kən/, / be/, $/ s \varepsilon /$, dan $/ k e /$.

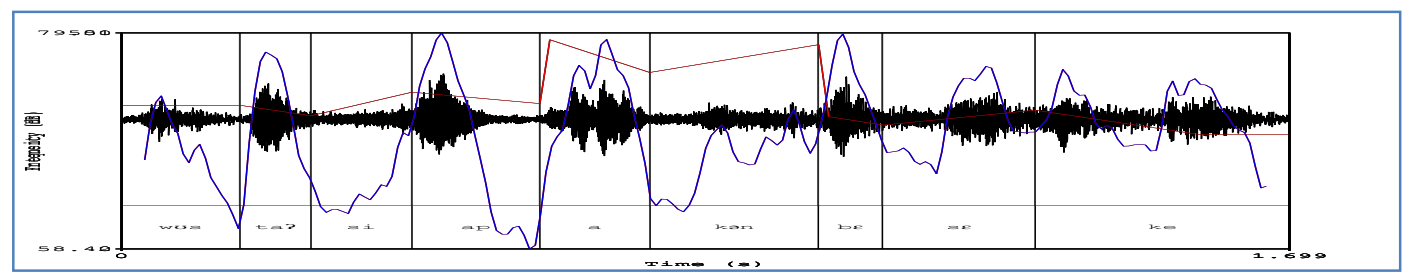

Gambar 1

Sinyal Akustik, Text Grid, Kontur Nada, dan Kontur Intensitas Tuturan Representatif wes ta? siapakən bescke 
Gambar 1 menunjukkan bahwa segmen 5 dan 6 memiliki karakter akustik yang kuat jika dibandingkan dengan segmen yang lain. Pada segmen tersebut direalisasikan bunyi /a/ dan $/ k ə n /$. Hal ini nampak pada gambar bahwa pada segmen tersebut direalisasikan dengan durasi yang cukup panjang (dilihat dari lebar segmen), intensitas yang kuat (dilihat dari fruktuasi garis biru), dan nada yang tinggi (dilihat dari fruktuasi garis berwarna merah). Segmen di kanan dan kirinya, yaitu segmen bunyi /ap/ dan / be/ juga terindikasi naik akibat penekanan bunyi /a/ dan $/ \mathrm{k} ə \mathrm{n} /$. Dalam studi fonetik akustik setiap segmen tersebut dapat dijelaskan parameter akustiknya, baik durasi, frekuensi, maupun intensitasnya. Gambar 1 tersebut menunjukkan pitch contour tuturan yang diawali dengan pitch movement rendah yang meninggi di tengah tuturan dan kembali merendah di akhir tuturan. Pusat penekannya ditengah tuturan pada bunyi /a/ dan $/ k \partial n /$. Secara morfologis, -aken merupakan imbuhan dalam bahasa Jawa. Jadi antara bunyi /a/ dan / kən/sebenarnya merupakan kesatuan yang tidak dapat dipisahkan satu sama lainnya. Imbuhan ini juga merupakan penanda utama dalam dialek bahasa Banten. Masyarakat Jawa Banten tidak mengenal imbuhan -ke melainkan -aken, seperti imbuhan ragam karma dalam bahasa Jawa standar.

Gambar 1 di atas belum cukup lengkap memberikan informasi yang akurat mengenai karakter dan identitas tuturan. Hanya saja Gambar 1 di atas dapat membantu dalam mendeskripsikan karakter akustik tuturan berdasarkan besaran parameter akustik yang membangunnya pada tiap-tiap segmen.Untuk akurasi yang tinggi memang tuturan tersebut harus diekstrak menjadi satuan bunyi silabis dan diukur kembali satuan bunyi tersebut sehingga menghasilkan parameter yang lebih akurat, lengkap, dan detail.

\section{Identifikasi Silabe /wus/}

Bunyi silabis /wus/ dituturkan dengan durasi 0,172md dengan rentang durasi antara 0,000md sampai dengan 0,172md pada tempo tuturan sebesar 1,699md. Puncak intensitasnya sebesar 73,40dB pada durasi 0,056md. Alir nadanya dapat dilihat pada Grafik 1 di bawah ini.

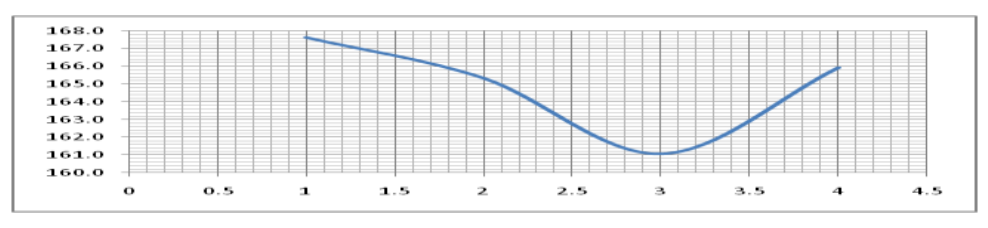

Grafik 1

Alir Nada Bunyi Silabis /wus/ 
Grafik 1 menunjukkan bahwa alir nada bunyi silabis /wus/ direalisasikan atas empat poin, yaitu (P1) sebesar 167,6 Hz yang direalisasi pada durasi 0,111md, (P2) sebesar 165,3 $\mathrm{Hz}$ yang direalisasi pada durasi $0,121 \mathrm{md}$, (P3) sebesar $161,1 \mathrm{~Hz}$ yang direalisasi pada durasi 0,141md, dan (P4) sebesar 165,9 Hz yang direalisasi pada durasi 0,151md.

\section{Identifikasi Silabe /ta?/}

Bunyi silabis /ta?/ dituturkan dengan durasi 0,103md dengan rentang durasi antara 0,172md sampai dengan $0,275 \mathrm{md}$ pada tempo tuturan sebesar $1,699 \mathrm{md}$. Puncak intensitasnya sebesar 77,68dB pada durasi 0,212md. Alir nadanya dapat dilihat pada Grafik 2 di bawah ini.

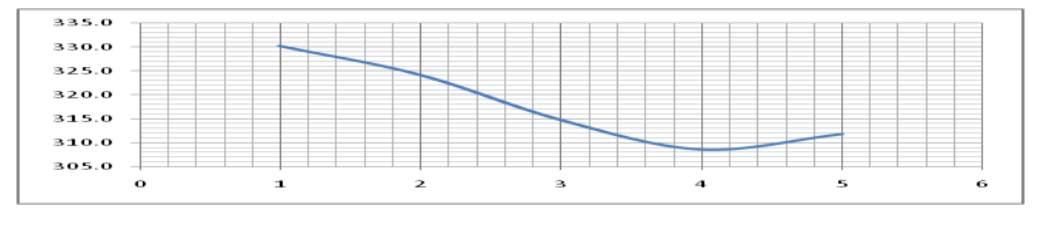

Grafik 2

Alir Nada Bunyi Silabis /ta?/

Grafik 2 menunjukkan bahwa alir nada bunyi silabis /ta?/ terdiri atas lima poin, yaitu (P1) sebesar 330,2 Hz yang direalisasi pada durasi 0,021md, (P2) sebesar 324,1 Hz yang direalisasi pada durasi 0,041md, (P3) sebesar 314,7 Hz yang direalisasi padadurasi $0,061 \mathrm{md}$, (P4) sebesar 308,6 Hz yang direalisasi pada durasi 0,071md, dan (P5) sebesar 311,8 Hz yang direalisasi pada durasi $0,081 \mathrm{md}$.

\section{Identifikasi Silabe /si/}

Bunyi silabis /si/ dituturkan dengan durasi 0,147md dengan rentang durasi antara 0,275md sampai dengan 0,422md pada tempo tuturan sebesar 1,699md. Puncak intensitasnya sebesar 64,83dB pada durasi 0,344md. Alir nadanya dapat dilihat pada Grafik 3 di bawah ini.

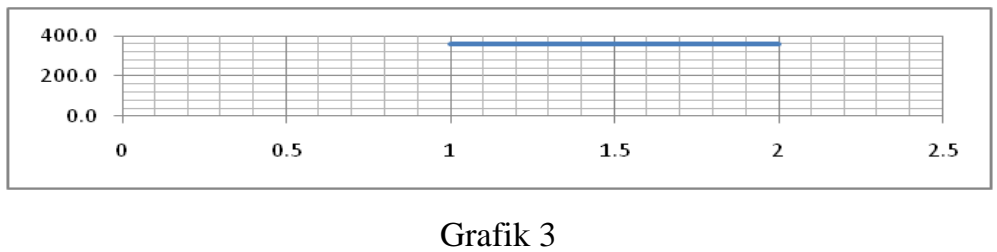

Alir Nada Bunyi Silabis /si/

Grafik 3 menunjukkan bahwa alir nada bunyi silabis /si/ terdiri atas dua poin, yaitu (P1) sebesar 316,0 Hz yang direalisasi pada durasi 0,103md dan (P2) sebesar 316,0 Hz yang direalisasi pada durasi 0,123md. Segmen /si/ memiliki alir nada flat. 


\section{Identifikasi Silabe /ap/}

Bunyi silabis /ap/ dituturkan dengan durasi 0,186md dengan rentang durasi antara 0,422md sampai dengan 0,608md pada tempo tuturan sebesar 1,699md. Puncak intensitasnya sebesar 79,56dB pada durasi 0,465md. Alir nadanya dapat dilihat pada Grafik 4 di bawah ini.

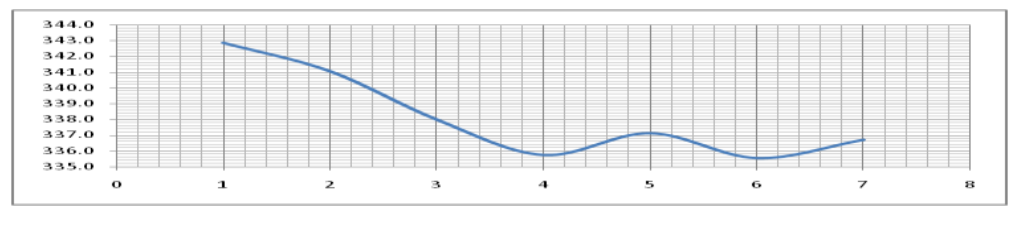

Grafik 4

Alir Nada Bunyi Silabis /ap/

Grafik 4 tersebut menunjukkan bahwa alir nada bunyi silabis /ap/terdiri atas tujuh poin, yaitu (P1) sebesar 342,8Hz yang direalisasi pada durasi 0,023md, (P2) sebesar 341,0Hz yang direalisasi pada durasi 0,043md, (P3) sebesar 338,0 Hz yang direalisasi pada durasi 0,063md, (P4) sebesar 335,7Hz yang direalisasi pada durasi 0,113md, (P5) sebesar 337,1 Hz yang direalisasi pada durasi 0,133md, (P6) sebesar 335,5Hz yang direalisasi pada durasi $0,153 \mathrm{md}$, dan (P7) sebesar $336,7 \mathrm{~Hz}$ yang direalisasi pada durasi $0,163 \mathrm{md}$.

\section{Identifikasi Silabe /a/}

Bunyi silabis /a/ dituturkan dengan durasi 0,160md dengan rentang durasi antara 0,608md sampai dengan 0,768md pada tempo tuturan sebesar 1,699md. Puncak intensitasnya sebesar 78,92dB pada durasi 0,703md. Alir nadanya dapat dilihat pada Grafik 5 di bawah ini.

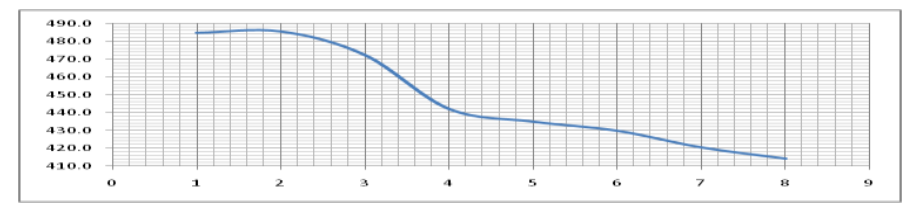

Grafik 5

Alir Nada Bunyi Silabis /al

Grafik 5 tersebut menunjukkan bahwa alir nada bunyi silabis /a/ terdiri atas delapan poin, yaitu (P1) sebesar 484,7Hz yang direalisasi pada durasi 0,020md, (P2) sebesar 485,4Hz yang direalisasi pada durasi 0,030md, (P3) sebesar 472,2 Hz yang direalisasi pada durasi 0,050md, (P4) sebesar 441,9Hz yang direalisasi pada durasi 0,080md, (P5) sebesar 434,8Hz yang direalisasi pada durasi $0,090 \mathrm{md}$, (P6) sebesar $429,7 \mathrm{~Hz}$ yang direalisasi pada durasi 0,100md, (P7) sebesar 420,4Hz yang direalisasi pada durasi 0,120md, dan (P8) sebesar $414,1 \mathrm{~Hz}$ yang direalisasi pada durasi $0,140 \mathrm{md}$. 


\section{Identifikasi Silabe /kon/}

Bunyi silabis $/ k ə n /$ dituturkan dengan durasi 0,246md dengan rentang durasi antara 0,768md sampai dengan 1,014md pada tempo tuturan sebesar 1,699md. Puncak intensitasnya sebesar 70,54dB pada durasi 0,872md. Alir nadanya dapat dilihat pada Grafik 6 di bawah ini.

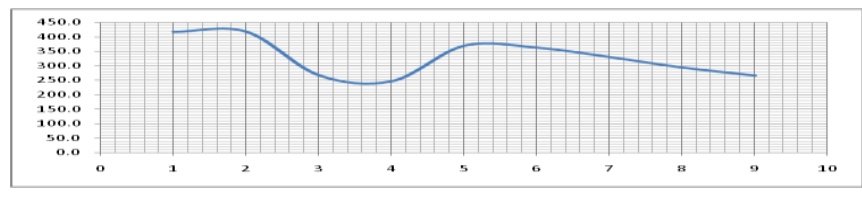

Grafik 6

Alir Nada Bunyi Silabis / kan/

Grafik 6 menunjukkan bahwa alir nada bunyi silabis $/ k \partial n /$ terdiri atas sembilan poin, yaitu (P1) sebesar 416,9Hz yang direalisasi pada durasi $0,022 \mathrm{md}$, (P2) sebesar 417,3Hz yang direalisasi pada durasi $0,032 \mathrm{md}$, (P3) sebesar 267,8Hz yang direalisasi pada durasi $0,062 \mathrm{md}$, (P4) sebesar $247,2 \mathrm{~Hz}$ yang direalisasi pada durasi 0,102md, (P5) sebesar 369,3 Hz yang direalisasi pada durasi 0,172md, (P6) sebesar 362,6Hz yang direalisasi pada durasi 0,192md, (P7) sebesar 330,3Hz yang direalisasi pada durasi 0,202md, (P8) sebesar 294,4Hz yang direalisasi pada durasi $0,212 \mathrm{md}$, dan (P9) sebesar $266,8 \mathrm{~Hz}$ yang direalisasi pada durasi $0,222 \mathrm{md}$.

\section{Identifikasi Silabe $/ b \varepsilon /$}

Bunyi silabis $/ b \varepsilon /$ dituturkan dengan durasi 0,093md dengan rentang durasi antara 1,014md sampai dengan 1,107md pada tempo tuturan sebesar 1,699md. Puncak intensitasnya sebesar 79,44dB pada durasi 1,048md. Alir nadanya dapat dilihat pada Grafik 7 di bawah ini.

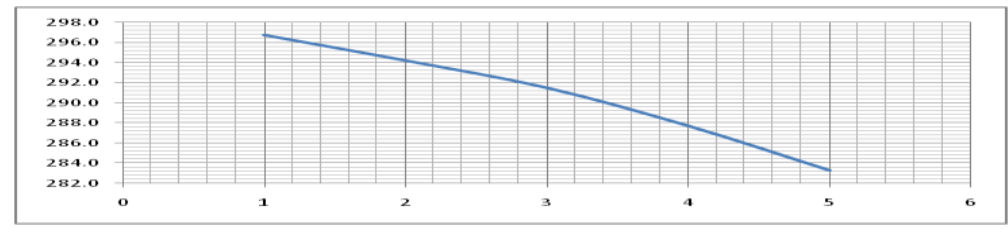

Grafik 7

Alir Nada Bunyi Silabis $/ b \varepsilon /$

Grafik 7 menunjukkan bahwa alir nada bunyi silabis $/ b \varepsilon /$ terdiri atas lima poin, yaitu (P1) sebesar 296,7Hz yang direalisasi pada durasi 0,021md, (P2) sebesar 294,2 Hz yang direalisasi pada durasi $0,031 \mathrm{md}$, (P3) sebesar 291,5Hz yang direalisasi pada durasi $0,041 \mathrm{md}$, (P4) sebesar $287,7 \mathrm{~Hz}$ yang direalisasi pada durasi $0,051 \mathrm{md}$, dan (P5) sebesar 283,3Hz yang direalisasi pada durasi $0,071 \mathrm{md}$. 


\section{Identifikasi Silabe /s\&/}

Bunyi silabis /s $\varepsilon$ /dituturkan dengan durasi 0,222md dengan rentang durasi antara $1,107 \mathrm{md}$ sampai dengan 1,329md pada tempo tuturan sebesar 1,699md. Puncak intensitasnya sebesar 76,30dB pada durasi 1,260md. Kemudian, alir nadanya dapat dilihat pada Grafik 8 di bawah ini.

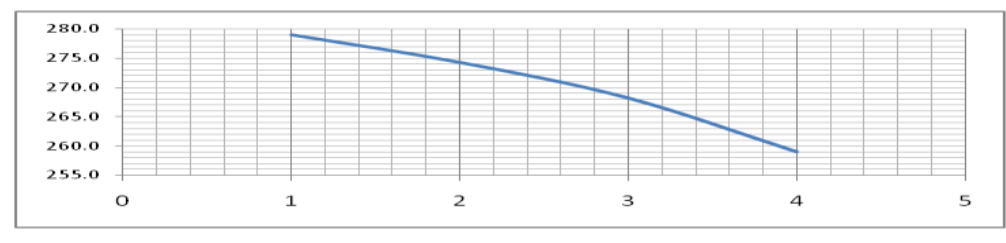

Grafik 8

Alir Nada Bunyi Silabis /se/

Grafik 8 tersebut menunjukkan bahwa alir nada bunyi silabis /se/ terdiri atas empat poin, yaitu poin pertama (P1) sebesar $279,0 \mathrm{~Hz}$ yang direalisasi pada durasi $0,101 \mathrm{md}$, poin kedua (P2) sebesar 274,3 Hz yang direalisasi pada durasi $0,111 \mathrm{md}$, poin ketiga (P3) sebesar 268,2 Hz yang direalisasi pada durasi $0,121 \mathrm{md}$, dan poin keempat (P4) sebesar 259,1 Hz yang direalisasi pada durasi $0,131 \mathrm{md}$.

\section{Identifikasi Silabe /ke/}

Bunyi silabis /ke/ dituturkan dengan durasi 0,370md dengan rentang durasi antara 1,329md sampai dengan 1,699md pada tempo tuturan sebesar 1,699md. Puncak intensitasnya sebesar 75,99dB pada durasi 1,371md. Alir nadanya dapat dilihat pada Grafik 9 di bawah ini.

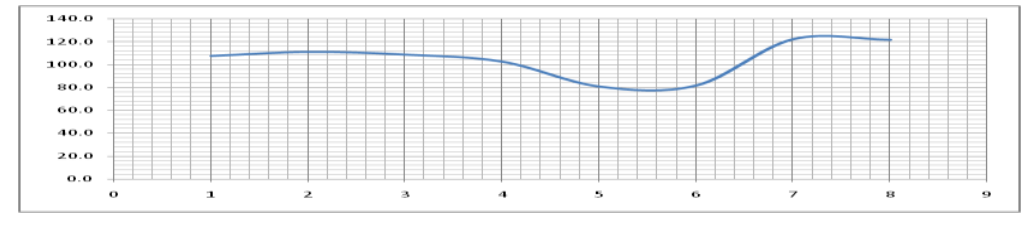

Grafik 9

Alir Nada Bunyi Silabis /ke/

Grafik 9 menunjukkan bahwa alir nada bunyi silabis /ke/ terdiri atas delapan poin, yaitu (P1) sebesar $107,5 \mathrm{~Hz}$ yang direalisasi pada durasi 0,104md, (P2) sebesar 111,0 Hz yang direalisasi pada durasi $0,124 \mathrm{md}$, (P3) sebesar 108,7Hz yang direalisasi pada durasi $0,134 \mathrm{md}$, (P4) sebesar $102,5 \mathrm{~Hz}$ yang direalisasi pada durasi 0,254md, (P5) sebesar 80,6 Hz yang direalisasi pada durasi 0,264md, (P6) sebesar $81,6 \mathrm{~Hz}$ yang direalisasi pada durasi $0,284 \mathrm{md}$, (P7) sebesar $122,2 \mathrm{~Hz}$ yang direalisasi pada durasi $0,294 \mathrm{md}$, dan (P8) sebesar $121,7 \mathrm{~Hz}$ yang direalisasi pada durasi $0,304 \mathrm{md}$. 


\section{PENUTUP}

Sinyal akustik tuturan representatif wes ta? siapakən bescke dibangun atas sembilan bunyi silabis, yaitu /wes/, /taP/, /si/, /ap/,/a/,/kan/, / be/, /se/, dan /ke/. Tuturan ini dituturkan dalam tempo 1,699md. Durasi terpendek direalisasikan pada bunyi silabis /ta?/ dengan panjang durasi $0,103 \mathrm{md}$, sedangkan durasi terpanjang direalisasikan pada bunyi silabis $/ \mathrm{k} ə \mathrm{n} /$ dengan panjang durasi 0,246 md. Intensitas terendah direalisasikan pada bunyi silabis /si/ sebesar $64,83 \mathrm{~dB}$, sedangkan intensitas tertinggi direalisasikan pada bunyi silabis /a/ sebesar $78,92 \mathrm{~dB}$. Pitch movement yang paling kentara sebagai penanda tuturan adalah pada bunyi silabis $/ a /, / k ə n /$, dan $/ k e /$. Bunyi ini direalisasikan dengan pitch movement yang fruktuatif dan variatif serta memiliki irama khas sebagai penanda akustik tuturan representatif bahasa Jawa dialek Banten. Pada silabel itu ditandai alir nada naik, turun, naik, dan turun kembali dengan durasi yang lebih panjang daripada silabel yang lain.

Hasil penelitian ini dapat dijadikan data acuan dalam upaya melakukan rekonstruksi bahasa Jawa dialek Banten, khususnya struktur akustik tuturannya jika suatu saat nanti diperlukan, seperti untuk pembelajaran bahasa Jawa sebagai muatan lokal di sekolah dasar di provinsi Banten. Caranya, data tuturan ini dapat dikonversi kembali menjadi tuturan sintetis. Hanya saja diperlukan piranti/perangkat yang mendukung untuk melakukan rekonstruksi ini.

\section{DAFTAR PUSTAKA}

Alario, F.-Xavier, dkk (2010).The Functional Origin of the Foreign Accent: Evidence From the Syllable-Frequency Effectin Bilingual Speakers.Psychological Science, 21(1), 15-20. https://doi.org/10.1177/0956797609354725

Alwasilah Chaedar. (1993). Pengantar Sosiologi Bahasa. Bandung: Angkasa.

Brazil, dkk. (1981). Discourse Intonation dan Language Teaching.Singapore: Longman

Cardoso, Walcir. (2011). The Development of Coda Perception in Second, Language Phonology: A Variationist Perspective.Second Language Research, 27(4), 433- 465. https://doi.org/10.1177/0267658311413540

Chaer, Abdul. (2009). Psikolinguistik Kajian Teoritik. Jakarta: Rineka Cipta.

Cruttenden, Alan. (1997). Intonation. Cambrige: Cambrige University Press. https://doi.org/10.1017/CBO9781139166973

Dardjowidjojo, S. (2005). Psikolinguistik Pengantar Pemahaman Bahasa Manusia. Jakarta: Yayasan Obor Indonesia.

Jackson, Carrie N. (2011). The Interaction between Prosody and Meaning in Second Language Speech Production.Die Unterrichtspraxis / Teaching German, 44(1), 1-11. https://doi.org/10.1111/j.1756-1221.2011.00087.x

Johnson, Keith. (2005). Acoustic and Auditory Phonetic. Australia: Blackwell. 
Kang, Okim, dkk (2010). Suprasegmental Measures of Accentedness and Judgments of Language Learner Proficiency in Oral English.The Modern Language Journal, 94(4). 554-566. https://doi.org/10.1111/j.1540-4781.2010.01091.x

Nooteboom, Sieb. (1999). The Prosody of Speech: Melody and Rhythm. Dalam Hardcastle, William J. and John Laver. 1999. The Handbook of Phonetics Sciences. Oxford: Basil Blackwell.

Prihartono, Wawan. (2012). Ciri Akustik Tuturan Modus Deklaratif Bahasa Jawa Penutur di Medan (Perbandingan dengan Ciri Akustik Tuturan Modus Deklaratif Bahasa Jawa Penutur di Solo). Medan: Tesis USU.

Pusat Bahasa. (2008). Bahasa dan Peta Bahasa di Indonesia. Jakarta: Pusat Bahasa, Depatemen Pendidikan Nasional.

Sasangka, Sry Satriya Tjatur Wisnu. (2004). Unggah-Ungguh Bahasa Jawa. Jakarta: Yayasan Paramalingua.

Stilp, Christian E, dkk. (2010). Rapid efficient coding of correlated complex acoustic properties. Proceedings of the National Academy of Sciences of the United States of America, 107(50), 21914-21919. https://doi.org/10.1073/pnas.1009020107

Wassid, Iskandar. (1985). Struktur Bahasa Jawa Banten. Jakarta: Pusat Pembinaan dan Pengembangan Bahasa. Kementerian Pendidikan dan Kebudayaan. 